\title{
Vertical and Horizontal Gradients in Aerosol Black Carbon and Its Mass Fraction to Composite Aerosols over the East Coast of Peninsular India from Aircraft Measurements
}

\author{
S. Suresh Babu, ${ }^{1}$ K. Krishna Moorthy, ${ }^{1}$ and S. K. Satheesh ${ }^{2}$ \\ ${ }^{1}$ Space Physics Laboratory, Vikram Sarabhai Space Centre, Trivandrum 695022, India \\ ${ }^{2}$ Centre for Atmospheric and Oceanic Sciences, Indian Institute of Science, Bangalore 560012, India
}

Correspondence should be addressed to S. Suresh Babu, s_sureshbabu@vssc.gov.in

Received 4 January 2010; Accepted 18 March 2010

Academic Editor: Victoria E. Cachorro

Copyright () 2010 S. Suresh Babu et al. This is an open access article distributed under the Creative Commons Attribution License, which permits unrestricted use, distribution, and reproduction in any medium, provided the original work is properly cited.

\begin{abstract}
During the Integrated Campaign for Aerosols, gases and Radiation Budget (ICARB) experiment of ISRO-GBP, altitude profiles of mass concentrations of aerosol black carbon $\left(\mathrm{M}_{\mathrm{B}}\right)$ and total (composite) aerosols $\left(\mathrm{M}_{\mathrm{T}}\right)$ in the lower troposphere were made onboard an aircraft from an urban location, Chennai $\left(13.04^{\circ} \mathrm{N}, 80.17^{\circ} \mathrm{E}\right)$. The profiling was carried out up to $3 \mathrm{~km}(\mathrm{AGL})$ in eight levels to obtain higher resolution in altitude. Besides, to explore the horizontal gradient in the vertical profiles, measurements were made at two levels $\left[500 \mathrm{~m}\right.$ (within ABL) and $1500 \mathrm{~m}$ (above ABL)] from $\sim 10^{\circ} \mathrm{N}$ to $16^{\circ} \mathrm{N}$ and $\sim 80^{\circ} \mathrm{E}$ to $84^{\circ} \mathrm{E}$. The profiles showed a significant vertical extent of aerosols over coastal and offshore regions around Chennai with BC concentrations $\left(\sim 2 \mu \mathrm{g} \mathrm{m}{ }^{-3}\right)$ and its contribution to composite aerosols remaining at the same level (between 8 to $10 \%$ for $\mathrm{F}_{\mathrm{BC}}$ ) as at the surface. Even though the values are not unusually high as far as an urban location is concerned, but their constancy throughout the vertical column will have important implications to climate impact of aerosols.
\end{abstract}

\section{Introduction}

Direct radiative forcing due to black carbon (BC) aerosols crucially depends on the vertical profile of BC. Elevated BC layer over scattering aerosol/cloud layer will enhance the atmospheric forcing and can even reverse the "white house effect" [1]. Tripathi et al. [2] have reported that the difference in the short-wave, clear sky forcing between the steadily decreasing and increasing $\mathrm{BC}$ aloft is as much as a factor of 1.3. Lubin et al. [3] have shown that this difference can be as much as a factor of two in the case of long wave. Haywood and Ramaswamy [4] have reported from GCM simulation that the direct radiative forcing of a $\mathrm{BC}$ aerosol layer increases approximately by a factor of 5 , as the layer is moved between the surface and $20 \mathrm{~km}$. Based on model simulation and observation during INDOEX, Ackerman et al. [5] reported that enhanced layer of $\mathrm{BC}$ aerosols reduces the cloud cover by $\mathrm{BC}$-induced atmospheric heating and hence offsets the aerosol-induced radiative cooling at the top of the atmosphere on a regional scale. Thus information on the altitude variation of $\mathrm{BC}$ and its mass fraction to total composite aerosols is very important in estimating its radiative forcing.

Even though LIDAR can give information on the vertical distribution of scattering aerosol, it cannot give any information on the altitude distribution of absorbing aerosols. Thus, in situ measurement of absorbing aerosol such as BC from aircraft is very important. Such measurements are very limited worldwide, especially over India except for Moorthy et al. [6], Tripathi et al. [2], and Babu et al. [7]. Nevertheless, these measurements were restricted only to BC mass concentration and were over inland locations. As part of the air segment of Integrated Campaign for Aerosols gases and Radiation Budget (ICARB) field experiment [8], altitude profiles of the mass concentrations of $\mathrm{BC}\left(\mathrm{M}_{\mathrm{B}}\right)$ and total $\left(\mathrm{M}_{\mathrm{T}}\right)$ aerosols were made over coastal areas of the urban centre of Chennai $\left(13.04^{\circ} \mathrm{N}, 80.17^{\circ} \mathrm{E}\right)$ in the east coast of India. 


\section{Experimental Details and Data Base}

Measurements were made onboard an aircraft (beach craft 20, propeller aircraft) of the National Remote Sensing Centre (NRSC) from the base at Chennai $\left(13.04^{\circ} \mathrm{N}, 80.17^{\circ} \mathrm{E}\right)$, a large urban centre situated on the eastern coast of India. Besides being a city with over 5 million population and the associate urban activities, automobiles and so forth, the city also has sound industries, very large port, and a thermal power station at its periphery. The instruments used were an Aethalometer; (model AE-42 of Magee Scientific, USA, [9]) for measuring mass concentrations $\left(\mathrm{M}_{B}\right)$ of BC and an Optical Particle Counter (OPC) spectrometer (model 1.108 of Grimm Aerosol Technique, Germany, [10]) operated in its mass mode for measuring the mass concentration $\left(\mathrm{M}_{\mathrm{T}}\right)$ of total (composite) aerosols. Aethalometer, a simple rugged instrument for field experiments, estimated $M_{B}$ by measuring the change in the transmittance of its quartz filter tape onto which the particles impinge [9]. The OPC is designed to measure particle size distribution and particulate mass based on the light scattering measurement of individual particles in the sampled air. The design and operation of the instrument are described in [10]. The instantaneous position of the aircraft at every second was recorded using a global positioning system (GPS).

The details of the sampling technique and configuring the above instruments in an aircraft are available elsewhere $[2,6]$. The instruments were mounted inside the cabin of the aircraft, which was kept unpressurised. The ambient air was aspirated through a stainless steel pipe, fitted to the body of the aircraft under its nose, such that the inlet opens into the incoming air as the aircraft flies. The inlets of the instruments were connected to the pipe using a Teflon tube, $\sim 1.5 \mathrm{~m}$ long.

The aethalometer estimated $\mathrm{M}_{\mathrm{B}}$ by measuring the change in the transmittance of its quartz filter tape onto which the particles impinge. The flow rate was determined by its internal pump operated under standard mass flow condition and the time base is programmable. The measured concentrations were corrected for the change in pumping speed caused by the change in the ambient pressure as the aircraft climbs to different height levels following the principle outlined in [6]. Reports are available in the recent literature on uncertainties in the aethalometer estimated BC [11-14] with several suggestions to account for it and these were followed in analyzing the data.

During the flight, the aethalometer was operated at a time base of 2 minutes and a flow rate of 6.5 standard liters per minute (under standard temperature $\left(T_{0}, 293 \mathrm{~K}\right.$ ) and pressure $\left.\left(P_{0}, 1017 \mathrm{hPa}\right)\right)$. However, because the ambient pressure decreases while the aircraft climbs higher, the pumping speed increases to maintain the set mass flow rate, and as such, more volume of air is aspirated. The actual volume $V$ of air aspirated at an ambient pressure $P$ and temperature $T$ is thus

$$
V=V_{0} \cdot \frac{P_{0}}{P} \cdot \frac{T}{T_{0}} .
$$

Since the measured $\mathrm{BC}$ concentrations $\left(\mathrm{M}_{\mathrm{B}}^{*}\right)$ are calculated based on standard flow rate $V_{0}$, the actual $\mathrm{BC}$ concentration $\mathrm{M}_{\mathrm{B}}$, after correcting for the change in flow rate, is

$$
\mathrm{M}_{\mathrm{B}}=\mathrm{M}_{\mathrm{B}}^{*}\left[\frac{P_{0} T}{P T_{0}}\right]^{-1} .
$$

Following the above equation each measurement of $\mathrm{M}_{\mathrm{B}}^{*}$ was converted to the true $\mathrm{BC}$ concentration $\mathrm{M}_{\mathrm{B}}$. Using the simultaneous measurements of $\mathrm{M}_{\mathrm{B}}$ and $\mathrm{M}_{\mathrm{T}}$, the $\mathrm{BC}$ mass fraction to total $\left(\mathrm{F}_{\mathrm{BC}}=\mathrm{M}_{\mathrm{B}} / \mathrm{M}_{\mathrm{T}}\right)$ was also estimated

2.1. Flight Details. The measurements were made between 1st April and 8th April 2006, during this period the aircraft made 6 sorties from Chennai towards the Bay of Bengal (BoB). The ground traces of the vertical profiling are shown in Figure 1(a). Each flight was configured distinctly to address different requirements of the experiment, so that a three-dimensional distribution of aerosols is obtained around the region. These included

(i) a high resolution vertical profiling (termed as spiral sortie) during which the aircraft made a nearly spiral ascent (about $50 \mathrm{~km}$ offshore from Chennai over the $\mathrm{BoB})$, making profile measurements at 8 levels within the altitude region $500 \mathrm{~m}$ to $3000 \mathrm{~m}$ above ground level. At each level, it flew for about 12 minutes horizontally, maintaining the same height as much as possible. The flight path of this profiling is shown in Figure 1(b). This sortie is made during the forenoon hours, after the local boundary layer has evolved well and gives a high-resolution profile in the lower atmosphere where the species concentration is very high;

(ii) a "latitudinal profiling" in which the aircraft covered a large latitudinal extent over coastal BoB, where concentrations are measured at two altitudes, one within the ABL $(500 \mathrm{~m})$ and one above it $(1500 \mathrm{~m})$, along a long horizontal track;

(iii) a "longitudinal profiling" in which the aircraft covered a large longitudinal extent, along particular latitude, similar to that done for latitudinal profiling.

\section{Prevailing Meteorology and Air Mass Back Trajectories}

The prevailing meteorology during the study period over off Chennai coast over Bay of Bengal was composed predominantly of calm synoptic conditions with weak winds, clear skies and absence of precipitation. No major weather systems or cyclonic depressions were encountered in the study area during the experiment. Aerosol properties over coastal oceanic regions would be significantly modified by the advection of aerosols from adjoining land masses under favourable wind conditions. With a view to examine the effect of air mass trajectories, which act as potential conduits for aerosol transport, using HYSPLIT (Hybrid Single Particle Lagrangian Integrated Trajectory) model 
of NOAA (http://www.arl.noaa.gov/ready/hysplit4.html), seven-day back trajectories for all days during the period of study were computed. Clusters of 7-day back trajectories arriving off Chennai for $500 \mathrm{~m}, 1500 \mathrm{~m}$, and $3000 \mathrm{~m}$ height levels are shown in Figure 2. It shows that the study region over $\mathrm{BoB}$ is influenced mainly by the advection from the peninsular India at $3000 \mathrm{~m}$ (free troposphere), whereas at lower levels, (500 m and $1500 \mathrm{~m}$ ) advection is mainly from costal India or coastal oceanic region with very few trajectories extending up to Indo-Gangetic plain.

\section{Results and Discussion}

4.1. Altitude Distribution. The altitude profile of $\mathrm{M}_{\mathrm{B}}, \mathrm{M}_{\mathrm{T}}$, and $F_{B C}$ are shown in Figures 3(a), 3(b), and 3(c), respectively. As, during the same period, the measurements of $M_{B}$ were also made onboard the ship ORV Sagar Kanya over the coastal oceanic region near to Chennai as a part of the ocean segment of ICARB [15] using a similar aethalometer, which is intercompared with the one onboard the aircraft, the data points corresponding to the surface are obtained as average of the shipboard measurements conducted in the same region. It is important and interesting to see that the vertical profiles of $\mathrm{M}_{\mathrm{B}}, \mathrm{M}_{\mathrm{T}}$, and $\mathrm{F}_{\mathrm{BC}}$ showed two peaks: one between 800 and $1000 \mathrm{~m}$ (which is bit broad) and a sharp peak at $\sim 1700 \mathrm{~m}$. At these peaks, $\mathrm{M}_{\mathrm{B}}$ values are in the range 2.5 to $3 \mu \mathrm{g} \mathrm{m}^{-3}$. Very high values of $\mathrm{M}_{\mathrm{B}}$ up to $12 \mu \mathrm{g} \mathrm{m}^{-3}$ were reported at altitudes $2.5 \mathrm{~km}$ from aircraft measurements during TRACE A experiment over Brazilian forests [16]. In addition to the common feature, $\mathrm{M}_{\mathrm{T}}$ showed an increasing trend with altitude from surface to $3 \mathrm{~km}$, with a positive gradient of $2.5 \pm 1.16 \mu \mathrm{g} \mathrm{m}^{-3} \mathrm{~km}^{-1}$, which lead to a weak decreasing trend in $\mathrm{F}_{\mathrm{BC}}$. Novakov et al. [17] reported an increasing trend in $\mathrm{F}_{\mathrm{BC}}$ with altitude during the aircraft measurements in the eastern coast of United States. Nevertheless, it was surprising to notice the large BC fraction as high as $8 \%$ even at $3 \mathrm{~km}$ above the surface.

At this juncture it is also interesting to compare the $\mathrm{M}_{\mathrm{B}}$ profile with a profile obtained (in February 2004) over the inland stations, Hyderabad $\left(17.75^{\circ} \mathrm{N}, 78.73^{\circ} \mathrm{E}\right.$, $557 \mathrm{~m}$ amsl, [6] and Kanpur $\left(26.43^{\circ} \mathrm{N}, 80.33^{\circ} \mathrm{E}, 142 \mathrm{~m}\right.$ amsl, [2]), which are shown by hollow circles connected by dotted line and triangles connected by dashed line, respectively, in Figure 3(a). Over both Hyderabad and Kanpur, $M_{B}$ showed a sharp decrease from surface to $500 \mathrm{~m}$ and above $500 \mathrm{~m}$ the values are more or less steady. However, over Kanpur a weak increase in $M_{B}$ at $\sim 900 \mathrm{~m}$ is seen. Over Chennai $M_{B}$ showed a nearly steady profile from surface to $3 \mathrm{~km}$ with a distinctive and broad peak with a layer thickness of $\sim 1 \mathrm{~km}$ from $\sim 750 \mathrm{~m}$ to $\sim 1750 \mathrm{~m}$.

Based on model calculations Haywood and Ramaswamy [4] have shown that the aerosol radiative forcing becomes higher when the $\mathrm{BC}$ is placed at high altitudes, especially above cloud layers. Keil and Haywood [18] have shown that a partially absorbing aerosol, such as biomass burning aerosol displaying a single scattering albedo in the range of 0.86 to 0.93 , overlying a sheet of stratocumulus causes a significant positive (warming) radiative effect as opposed to a negative

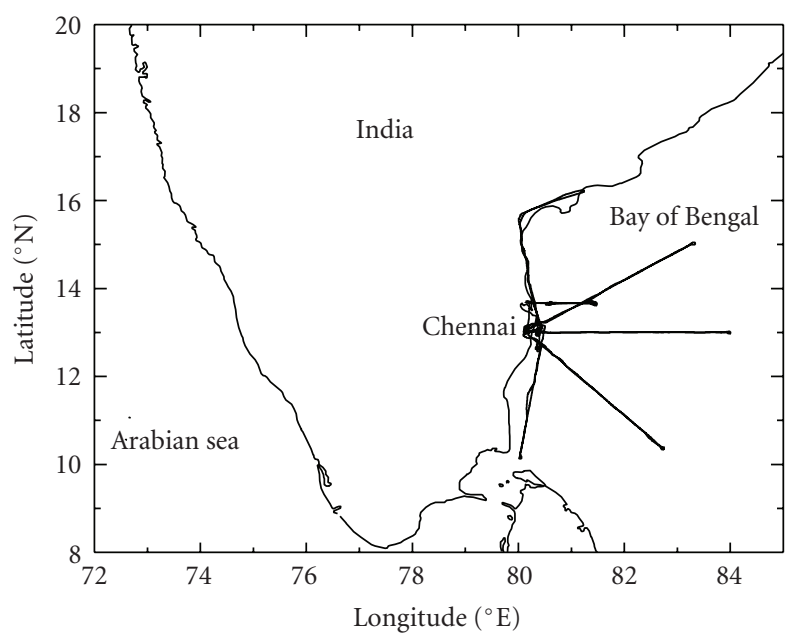

(a)

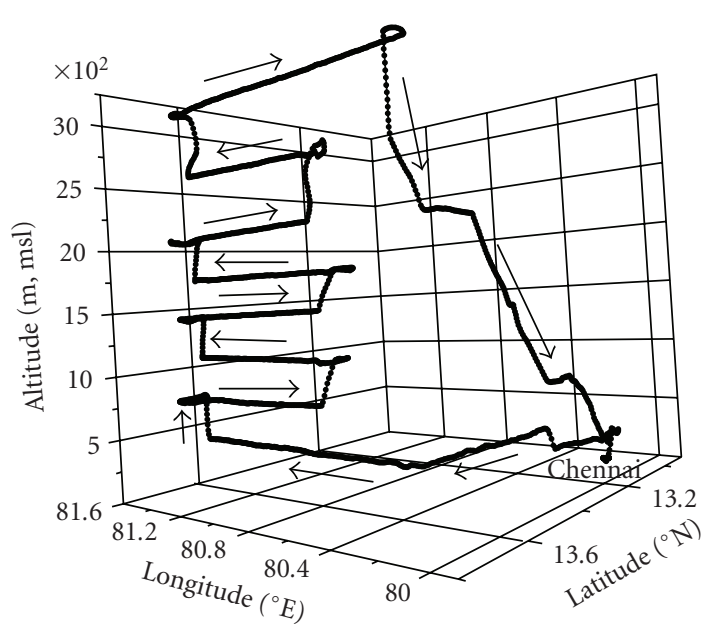

(b)

FIgURE 1: The flight paths of the aircraft from Chennai (a). The red line corresponds to the ground trace of the aircraft flight track during the multilevel sortie and the blue line corresponds to the ground trace of the sorties used for examining latitudinal gradient at two altitudes. (b) The track in which the high resolution vertical profiling was done at 8 levels.

(cooling) effect that would occur if the cloud was absent. Thus, the vertical positioning of aerosol and cloud layers can be crucial to both the sign and magnitude of local and regional radiative forcing. In the present study, we have visually observed a cloud layer from the aircraft between 500 and $800 \mathrm{~m}$. Above this cloud layer, both $\mathrm{M}_{\mathrm{B}}$ and $\mathrm{M}_{\mathrm{T}}$ showed a significant increase from the surface values. $M_{B}$ increases from $\sim 1.7 \mu \mathrm{g} \mathrm{m}^{-3}$ to $\sim 2.7 \mu \mathrm{g} \mathrm{m}^{-3}$ and $\mathrm{M}_{\mathrm{T}}$ increases from $\sim 18 \mu \mathrm{g} \mathrm{m}^{-3}$ to $\sim 25 \mu \mathrm{g} \mathrm{m}^{-3}$. However, the $\mathrm{F}_{\mathrm{BC}}$ values are found to be more or less same as that of the surface values except for the two peaks at 800 and $1700 \mathrm{~m}$. It is important to note that even though these values are not unusually high as far as an urban location is concerned, but their constancy throughout the vertical column will have important implications to climate impact assessment. 


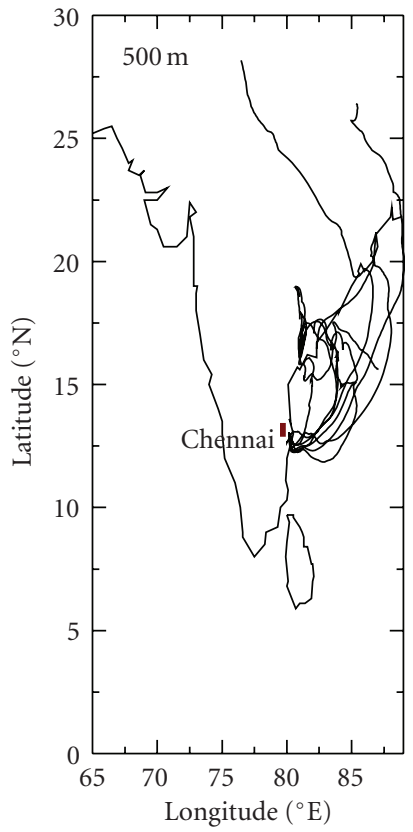

(a)

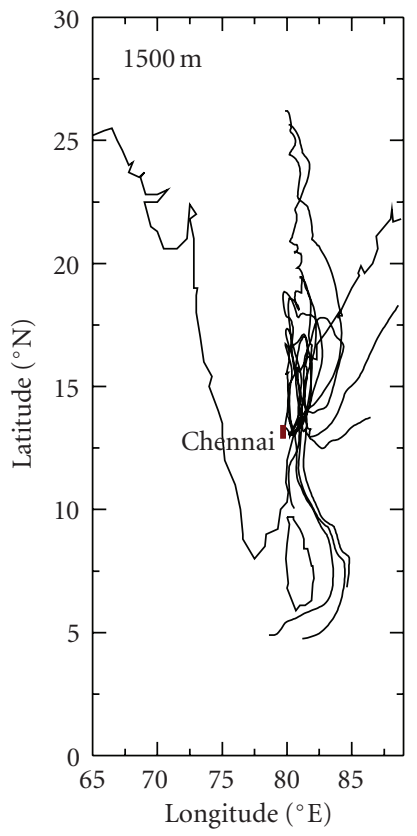

(b)

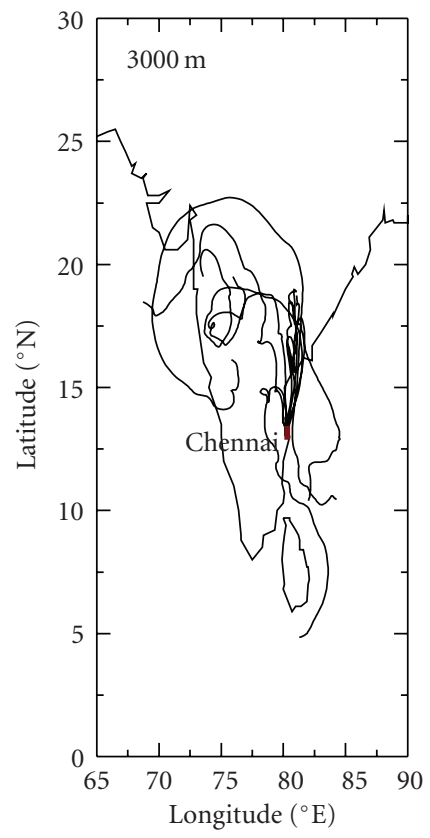

(c)

FIGURE 2: Airmass back trajectories arriving off Chennai coast at three different heights, 500, 1500, and $3000 \mathrm{~m}$ amsl, respectively.

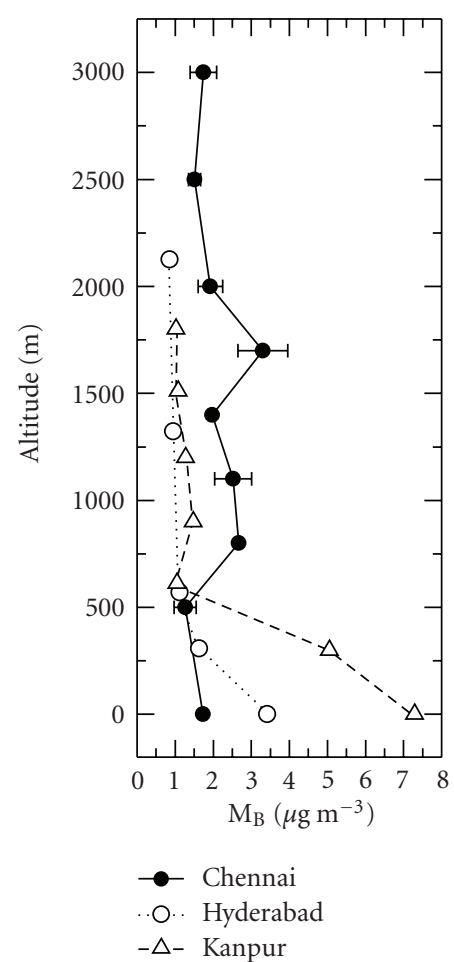

(a)
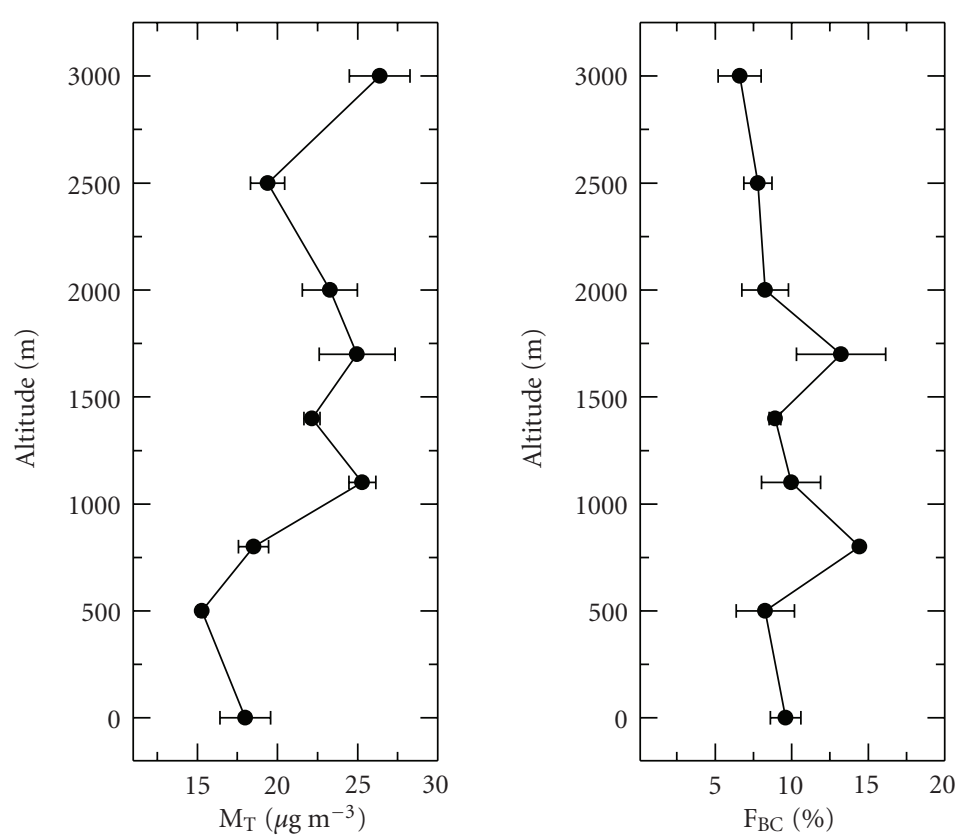

(b)

(c)

Figure 3: Altitude profiles of $\mathrm{M}_{\mathrm{B}}, \mathrm{M}_{\mathrm{T}}$, and $\mathrm{F}_{\mathrm{BC}}$ over the coastal oceanic region off Chennai. Altitude profile of $\mathrm{M}_{\mathrm{B}}$ over Hyderabad (circles with dotted line) and Kanpur (triangles with dashed line) are also shown in panel (a) for comparison. 


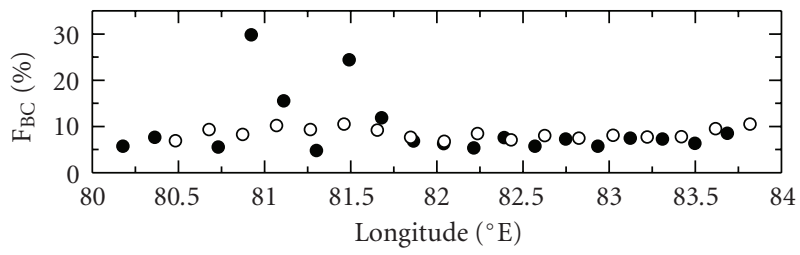

(a)

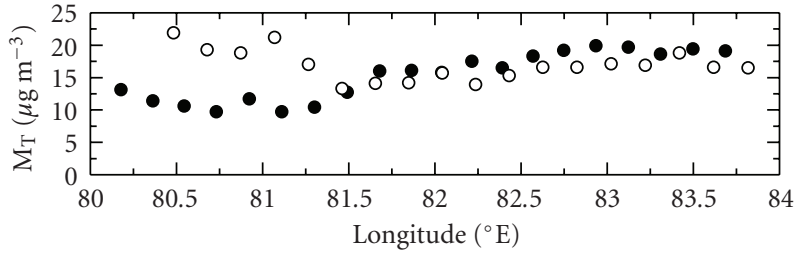

(b)

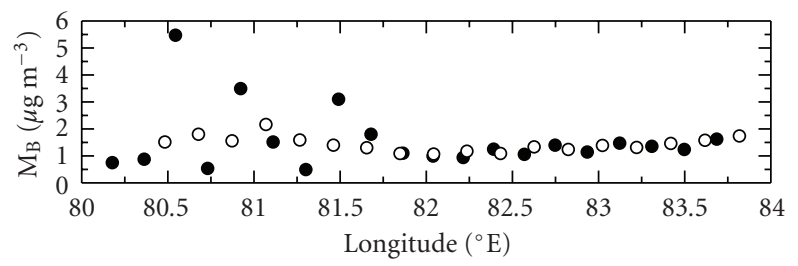

- $500 \mathrm{~m}$

○ $1500 \mathrm{~m}$

(c)

Figure 4: Longitudinal variation of $\mathrm{M}_{\mathrm{B}}, \mathrm{M}_{\mathrm{T}}$, and $\mathrm{F}_{\mathrm{BC}}$ at $500 \mathrm{~m}$ and $1500 \mathrm{~m}$.

4.2. Longitudinal Variations Normal to the Coastline. Advection of continental aerosols over to oceans is a strong input to marine aerosol system and has been drawing the attention of scientists and environmentalists. All the recent field experiments (ACE I \& II, TARFOX, INDOEX, ACE-Asia) have been extensively addressed to this problem. In the coastal region, this is accelerated by the mesoscale meteorological process such as land-sea breeze circulations. Based on a cruise experiment over the Arabian Sea, Subrahamanyam et al. [19] reported that the vertical extend of the sea breeze circulation cell can be up to $1.2 \mathrm{~km}$, and this can have an offshore extend of $\sim 100 \mathrm{~km}$. Based on model simulation Rani et al. [20] reported that the horizontal extend of land/sea breeze circulation over ocean can be up to $130 \mathrm{~km}$ away from the coast during pre-monsoon season. Keeping these in mind, we examined the longitudinal sortie, which was conducted at two levels, $500 \mathrm{~m}$ (within the marine boundary layer) and $1500 \mathrm{~m}$ (just above the marine boundary layer). These height levels are selected based on [21] from Chennai normal to the coastline as shown in Figure 1(a). The sortie covered a longitudinal span of $4^{\circ}$ into the ocean.

The longitudinal variation at $500 \mathrm{~m}$ and $1500 \mathrm{~m}$ are shown in Figure 4 for $M_{B}$ (c), $M_{T}$ (b) and $F_{B C}$ (a). In the figure, the filled circles correspond to the values at $500 \mathrm{~m}$ and the open circles correspond to the values at $1500 \mathrm{~m}$. Up to $\sim 81.5^{\circ} \mathrm{E}(\sim 130 \mathrm{~km}$ from the coast $), \mathrm{M}_{\mathrm{B}}$ at $500 \mathrm{~m}$ (within MABL) showed large fluctuations with values as low as $0.5 \mu \mathrm{g} \mathrm{m}^{-3}$ and as high as $5.5 \mu \mathrm{g} \mathrm{m}^{-3}$ with a mean value of $2 \pm 0.6 \mu \mathrm{g} \mathrm{m}^{-3}$, where as $\mathrm{M}_{\mathrm{B}}$ values at $1500 \mathrm{~m}$ in the same region was more or less steady with a mean value of $1.6 \pm$ $0.1 \mu \mathrm{g} \mathrm{m}^{-3}$. Beyond $81.5^{\circ} \mathrm{E}$, the $\mathrm{M}_{\mathrm{B}}$ values appeared to be nearly steady at both $500 \mathrm{~m}$ and $1500 \mathrm{~m}$. The mean values of $\mathrm{M}_{\mathrm{B}}$ beyond $81.5^{\circ} \mathrm{E}$ were $1.23 \pm 0.06 \mu \mathrm{g} \mathrm{m}^{-3}$ and $1.31 \pm$ $0.06 \mu \mathrm{g} \mathrm{m}^{-3}$, respectively, at $500 \mathrm{~m}$ and $1500 \mathrm{~m}$ levels.

Compared to $\mathrm{M}_{\mathrm{B}}, \mathrm{M}_{\mathrm{T}}$ showed a rather smooth variation at $500 \mathrm{~m}$ throughout the sortie varying between $\sim 10 \mu \mathrm{g} \mathrm{m}^{-3}$ and $\sim 20 \mu \mathrm{g} \mathrm{m}^{-3}$ with higher values farther from the coast (beyond $81.5^{\circ} \mathrm{E}$ ). More interestingly, $\mathrm{M}_{\mathrm{T}}$ values were higher at $1500 \mathrm{~m}$ than at $500 \mathrm{~m}$ in the near coastal region, up to $81.5^{\circ} \mathrm{E}$ and vice versa beyond $81.5^{\circ} \mathrm{E}$. However, $\mathrm{F}_{\mathrm{BC}}$ at both 500 and $1500 \mathrm{~m}$ showed longitudinal variations similar to that of $\mathrm{M}_{\mathrm{B}}$ with large variations in $\mathrm{M}_{\mathrm{B}}$ at $500 \mathrm{~m}$ up to $81.5^{\circ} \mathrm{E}$ (varies between $\sim 5 \%$ to $30 \%$ ) and almost steady beyond $81.5^{\circ} \mathrm{E}$. $\mathrm{F}_{\mathrm{BC}}$ at $1500 \mathrm{~m}$ shows more or less steady values throughout the sortie, varies between $7 \%$ and $10 \%$, with slightly higher values up to $81.5^{\circ} \mathrm{E}$. This, combined with Figure 3, indicates that $\sim 8$ to $10 \%$ of $\mathrm{F}_{\mathrm{BC}}$ prevails not only at the surface but extends up to $\sim 3 \mathrm{~km}$ vertically and $400 \mathrm{~km}\left(\sim 4^{\circ}\right)$ longitudinally across the coast into the deep oceanic regions. However, within the sea breeze circulation cell both $\mathrm{M}_{\mathrm{B}}$ and $\mathrm{F}_{\mathrm{BC}}$ (at $500 \mathrm{~m}$ ) showed large variations.

4.3. Latitudinal Variation along the Coast. Two sorties were made along the coast from Chennai to down south up to $\sim 10^{\circ} \mathrm{N}$ and to north up to $\sim 16^{\circ} \mathrm{N}$ again at the same two different levels, $500 \mathrm{~m}$ and $1500 \mathrm{~m}$ (on 2nd April and 6th April, 2006), and these data were used to examine the NorthSouth variation of $\mathrm{M}_{\mathrm{B}}, \mathrm{M}_{\mathrm{T}}$, and $\mathrm{F}_{\mathrm{BC}}$ along the coast. The results are shown in Figure 5. Both $\mathrm{M}_{\mathrm{B}}$ and $\mathrm{M}_{\mathrm{T}}$ showed an increasing trend at $500 \mathrm{~m}$ towards north, except the high values observed above Chennai due to the city impact. This was quite understandable as similar trends were seen in the latitudinal variation within MABL from the ship borne measurements also [15]. However, at $1500 \mathrm{~m}$, this trend reverses and high $\mathrm{M}_{\mathrm{B}}$ values were observed over the south of Chennai than that of the north. The variations are rather smooth and a steady decrease in $\mathrm{M}_{\mathrm{B}}$ with latitude is observed at $1500 \mathrm{~m}$ level. A linear regression analysis yielded $\sim 197 \mathrm{ng} \mathrm{m}^{-3}$ decrease in $\mathrm{M}_{\mathrm{B}}$ for every degree increase in the latitude, with a correlation coefficient of 0.64 . In the case 


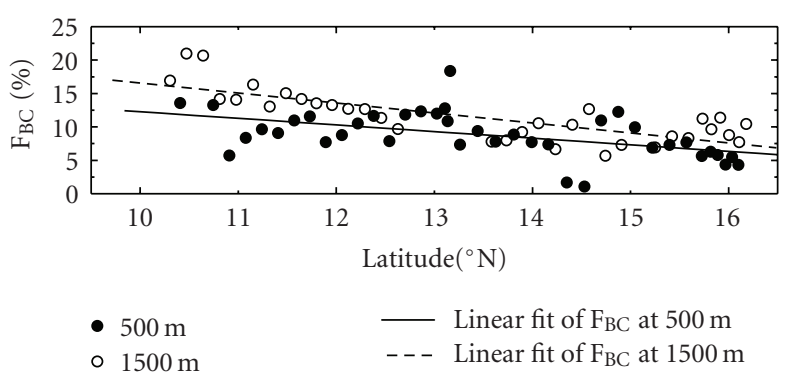

(a)

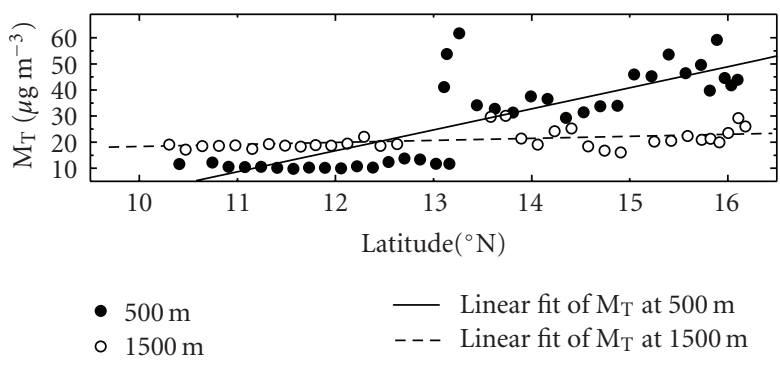

(b)

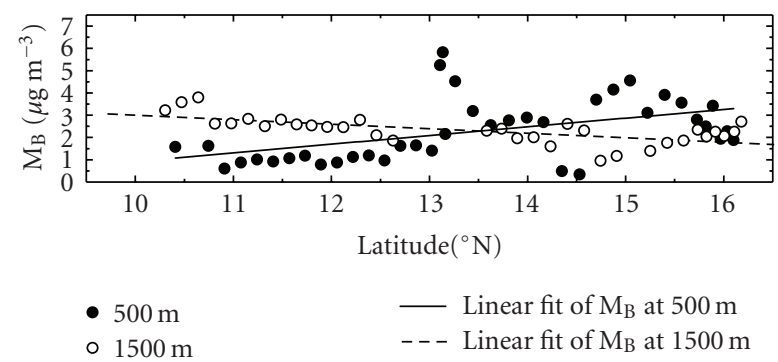

(c)

Figure 5: Latitudinal variation of $\mathrm{M}_{\mathrm{B}}, \mathrm{M}_{\mathrm{T}}$, and $\mathrm{F}_{\mathrm{BC}}$ at $500 \mathrm{~m}$ and $1500 \mathrm{~m}$.

of $\mathrm{M}_{\mathrm{T}}$, the correlation coefficient estimated at $500 \mathrm{~m}(0.81)$ is quite significant $(P<.0001)$ and is higher than that at $1500 \mathrm{~m}(0.45)$ where the $P=.01$. At $500 \mathrm{~m}$ the regression slope gives an increase of $\sim 8 \mu \mathrm{g} \mathrm{m}^{-3}$ in $\mathrm{M}_{\mathrm{T}}$ for every degree increase in latitude where as at $1500 \mathrm{~m}$ the regression slope gives a much smaller value of $\sim 0.84 \mu \mathrm{g} \mathrm{m}^{-3}$ for every degree increase in the latitude. At this juncture, it is interesting to note that based on a road campaign over peninsular India in 2004, Moorthy et al. [22] have observed a similar latitudinal variation in $\mathrm{M}_{\mathrm{B}}$ at the surface level during the winter season along the west coast of peninsular India.

The most interesting feature is the higher $\mathrm{F}_{\mathrm{BC}}$ values over the south of Chennai than that over north, even though the industrial and anthropogenic sources are distributed more to the north of Chennai. A consistent decrease in $\mathrm{F}_{\mathrm{BC}}$ was also observed from the south to north at 500 and $1500 \mathrm{~m}$ altitudes, irrespective of the latitudinal trends in $\mathrm{M}_{\mathrm{B}}$ and $\mathrm{M}_{\mathrm{T}}$. The fraction of $\mathrm{BC}$ in the aerosol system decreased northward above the MABL. This could be probably because of the large decrease in coarse mode particles aloft, leading to a sharper decrease in the mass concentration of composite aerosols than that of the MABL. It is interesting to note that, measurements onboard ship over the same region also indicated a steady $\mathrm{F}_{\mathrm{BC}}$ values $(\sim 3.0 \%)$ over the entire $\mathrm{BoB}$ [15].

\section{Conclusions}

During the Integrated Campaign for Aerosols, gases and Radiation Budget (ICARB) studies of ISRO-GBP, altitude profiles of mass concentrations of aerosol black carbon $\left(\mathrm{M}_{\mathrm{B}}\right)$ and total (composite) aerosols $\left(\mathrm{M}_{\mathrm{T}}\right)$ in the lower troposphere were made onboard an aircraft from an urban location,
Chennai. From the simultaneous measurements of $\mathrm{M}_{\mathrm{B}}$ and $\mathrm{M}_{\mathrm{T}}, \mathrm{BC}$ mass fraction $\left(\mathrm{F}_{\mathrm{BC}}\right)$ is derived. The profiles showed;

(i) a significant vertical extent of aerosols over coastal and offshore regions around Chennai with $\mathrm{BC}$ concentrations remaining at the same level as at the surface,

(ii) two distinct peaks, first one between $800 \mathrm{~m}$ and $1000 \mathrm{~m}$ and the second at around $1700 \mathrm{~m}$ where the concentrations are higher than that near the surface,

(iii) a near steady value (between 8 to $10 \%$ ) for $\mathrm{F}_{\mathrm{BC}}$ from ground to $3 \mathrm{~km}$ with two peaks at $\sim 800 \mathrm{~m}$ and $1700 \mathrm{~m}$ where $\mathrm{F}_{\mathrm{BC}}$ goes as high as $15 \%$ and a weak still significant increasing trend in $\mathrm{M}_{\mathrm{T}}$ from surface to $3 \mathrm{~km}$ with a positive gradient of $2.5 \pm$ $1.16 \mu \mathrm{g} \mathrm{m}^{-3} \mathrm{~km}^{-1}$.

(iv) Even though the values are not unusually high as far as an urban location is concerned, their constancy throughout the vertical column will have important implications to climate impact assessment.

\section{Acknowledgments}

This work formed as part of the ICARB experiment under ARFI project of ISRO-GBP. The authors wish to thank the crew of the aircraft for their help throughout the field campaign and wholehearted support of the NRSC aircraft team headed by Dr. K. Kalyanaraman and Mr. Raghu Venkataraman. They acknowledge the NOAA Air Resources Laboratory for the provision of the HYSPLIT transport and dispersion model and READY website (http://www.arl.noaa.gov/ready.html) used in this publication. 


\section{References}

[1] S. K. Satheesh, "Aerosol radiative forcing over land: effect of surface and cloud reflection," Annales Geophysicae, vol. 20, no. 12, pp. 2105-2109, 2002.

[2] S. N. Tripathi, S. Dey, V. Tare, S. K. Satheesh, S. Lal, and S. Venkataramani, "Enhanced layer of black carbon in a north Indian industrial city," Geophysical Research Letters, vol. 32, no. 12, Article ID L12802, 4 pages, 2005.

[3] D. Lubin, S. K. Satheesh, G. McFarquar, and A. J. Heymsfield, "Longwave radiative forcing of Indian Ocean tropospheric aerosol," Journal of Geophysical Research, vol. 107, article 8004, 13 pages, 2002.

[4] J. M. Haywood and V. Ramaswamy, "Global sensitivity studies of the direct radiative forcing due to anthropogenic sulfate and black carbon aerosols," Journal of Geophysical Research, vol. 103, no. D6, pp. 6043-6058, 1998.

[5] A. S. Ackerman, O. B. Toon, D. E. Stevens, A. J. Heymsfield, V. Ramanathan, and E. J. Welton, "Reduction of tropical cloudiness by soot," Science, vol. 288, no. 5468, pp. 1042-1047, 2000.

[6] K. K. Moorthy, S. S. Babu, S. V. Sunilkumar, P. K. Gupta, and B. S. Gera, "Altitude profiles of aerosol BC, derived from aircraft measurements over an inland urban location in India," Geophysical Research Letters, vol. 31, no. 22, Article ID L22103, 4 pages, 2004.

[7] S. S. Babu, S. K. Satheesh, K. K. Moorthy, et al., "Aircraft measurements of aerosol black carbon from a coastal location in the north-east part of peninsular India during ICARB," Journal of Earth System Science, vol. 117, supplement 1, pp. 263-271, 2008.

[8] K. K. Moorthy, S. K. Satheesh, S. S. Babu, and C. B. S. Dutt, "Integrated campaign for aerosols, gases and radiation budget (ICARB): an overview," Journal of Earth System, vol. 117, pp. 243-262, 2008.

[9] A. D. A. Hansen, H. Rosen, and T. Novakov, "The aethalometer, an instrument for the real-time measurement of optical absorption by aerosol particles," Science of the Total Environment, vol. 36, pp. 191-196, 1984.

[10] H. Grimm and D. J. Eatough, "Aerosol measurement: the use of optical light scattering for the determination of particulate size distribution, and particulate mass, including the semivolatile fraction," Journal of the Air and Waste Management Association, vol. 59, no. 1, pp. 101-107, 2009.

[11] E. Weingartner, H. Saathoff, M. Schnaiter, N. Streit, B. Bitnar, and U. Baltensperger, "Absorption of light by soot particles: determination of the absorption coefficient by means of aethalometers," Journal of Aerosol Science, vol. 34, no. 10, pp. 1445-1463, 2003.

[12] W. P. Arnott, K. Hamasha, H. Moosmüller, P. J. Sheridan, and J. A. Ogren, "Towards aerosol light-absorption measurements with a 7 -wavelength aethalometer: evaluation with a photoacoustic instrument and 3-wavelength nephelometer," Aerosol Science and Technology, vol. 39, no. 1, pp. 17-29, 2005.

[13] P. J. Sheridan, W. Patrick Arnott, J. A. Ogren, et al., "The reno aerosol optics study: an evaluation of aerosol absorption measurement methods," Aerosol Science and Technology, vol. 39, no. 1, pp. 1-16, 2005.

[14] C. E. Corrigan, V. Ramanathan, and J. J. Schauer, "Impact of monsoon transitions on the physical and optical properties of aerosols," Journal of Geophysical Research, vol. 111, no. 18, Article ID D18208, 2006.
[15] V. S. Nair, S. S. Babu, and K. K. Moorthy, "Aerosol characteristics in the marine atmospheric boundary layer over the Bay of Bengal and Arabian Sea during ICARB: spatial distribution and latitudinal and longitudinal gradients," Journal of Geophysical Research, vol. 113, no. 15, Article ID D15208, 2008.

[16] E. B. Pereira, A. W. Setzer, F. Gerab, P. E. Artaxo, M. C. Pereira, and G. Monroe, "Airborne measurements of aerosols from burning biomass in Brazil related to the TRACE A experiment," Journal of Geophysical Research, vol. 101, no. 19, pp. 23983-23992, 1996.

[17] T. Novakov, D. A. Hegg, and P. V. Hobbs, "Airborne measurements of carbonaceous aerosols on the East Coast of the United States," Journal of Geophysical Research, vol. 102, no. 25, pp. 30023-30030, 1997.

[18] A. Keil and J. M. Haywood, "Solar radiative forcing by biomass burning aerosol particles during SAFARI 2000: a case study based on measured aerosol and cloud properties," Journal of Geophysical Research, vol. 108, no. D13, article 8467, 2003.

[19] D. B. Subrahamanyam, K. Sen Gupta, S. Ravindran, and P. Krishnan, "Study of sea breeze and land breeze along the west coast of Indian sub-continent over the latitude range $15^{\circ} \mathrm{N}$ to $8^{\circ} \mathrm{N}$ during INDOEX IFP-99 (SK-141) cruise," Current Science, vol. 80, pp. 85-88, 2001.

[20] S. I. Rani, R. Ramachandran, D. B. Subrahamanyam, D. P. Alappattu, and P. K. Kunhikrishnan, "Characterization of sea/land breeze circulation along the west coast of Indian subcontinent during pre-monsoon season," Atmospheric Research, vol. 95, no. 4, pp. 367-378, 2010.

[21] V. Manghnani, S. Raman, D. S. Niyogi, et al., "Marine boundary-layer variability over the Indian Ocean during INDOEX (1998)," Boundary-Layer Meteorology, vol. 97, no. 3, pp. 411-430, 2000.

[22] K. K. Moorthy, S. S. Babu, K. V. Badarinath, S. V. Sunilkumar, T. R. Kiranchand, and Y. N. Ahmed, "Latitudinal distribution of aerosol black carbon and its mass fraction to composite aerosols over peninsular India during winter season," Geophysical Research Letters, vol. 34, no. 8, Article ID L08802, 2007. 

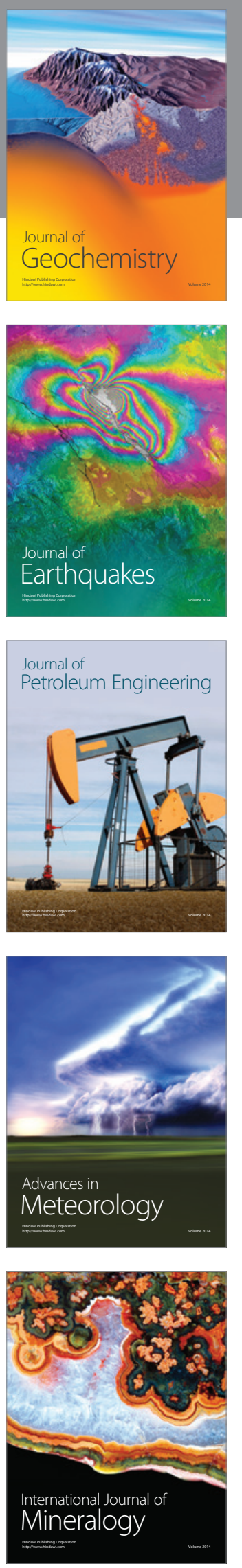
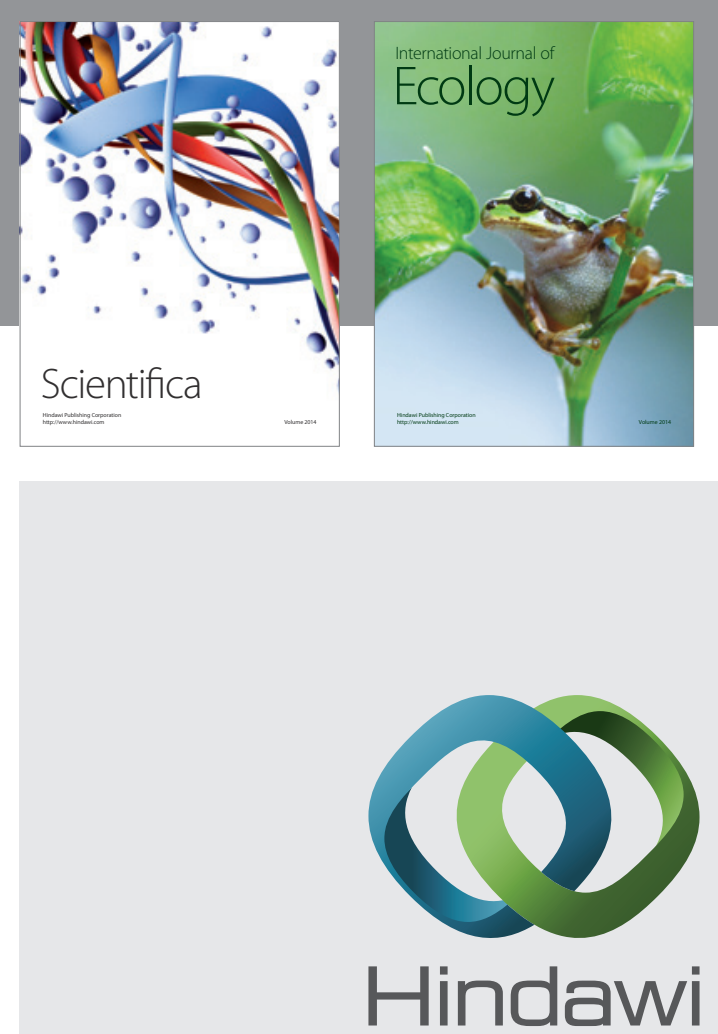

Submit your manuscripts at http://www.hindawi.com
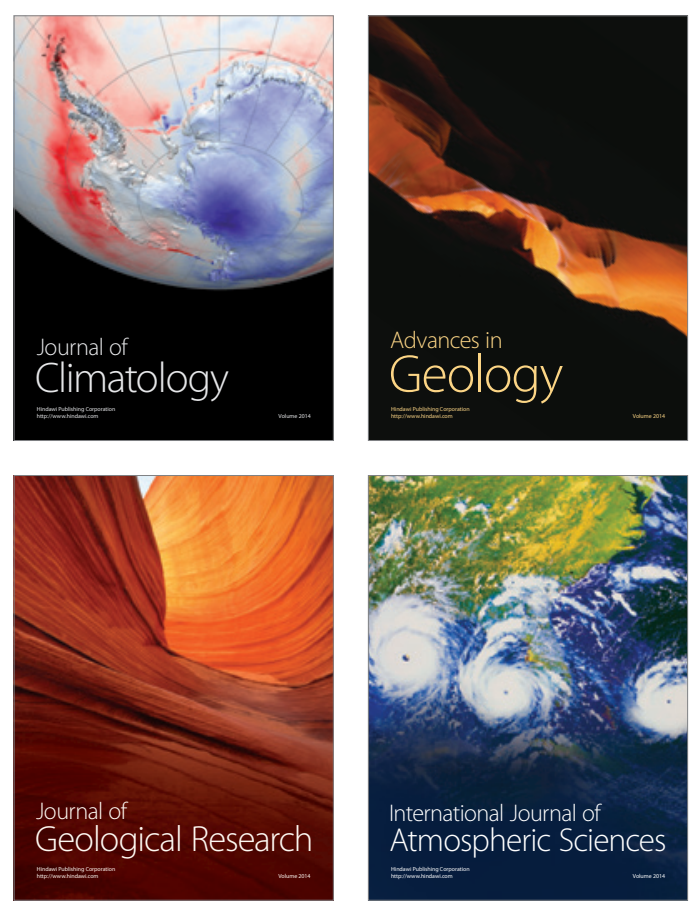
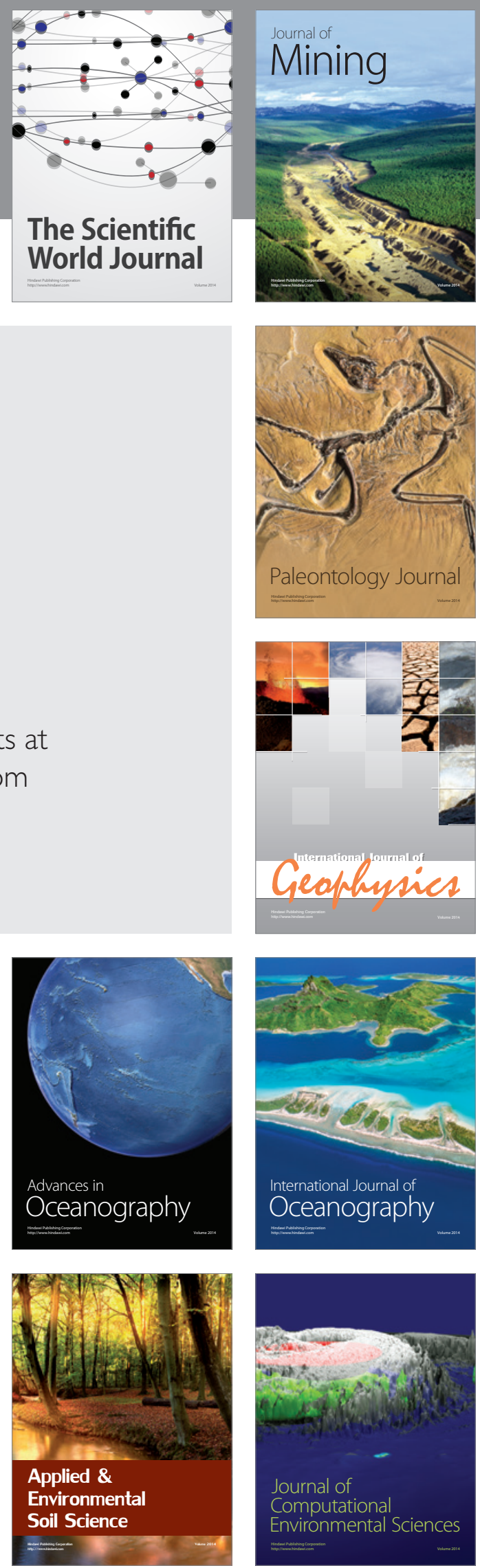